\title{
Perbandingan Simple Additive Weighting Dan Weighted Product Pada Keputusan Pemberian Bantuan (Desa Cisarua)
}

\author{
Rizka Aulia Fazri \\ Perangkat Lunak Sistem Informasi, Manajemen Sistem Informasi, Universitas Gunadarna \\ Jl. Margonda Raya No. 100, Pondok Cina, Depok 16424, (021) 78881112 \\ e-mail: rizkauliaf@gmail.com
}

\begin{abstract}
Abstrak
Pemberian bantuan merupakan salah satu program yang dilakukan pemerintah melalui perwakilan setiap daerah untuk membantu masyarakat, khususnya pihak yang saat ini terkena dampak pandemic virus Covid-19. Idealnya penentuan keputusan pemberian bantuan dapat dilakukan dengan cepat, bersifat objektif dan tepat sasaran. Namun dengan proses pengambilan keputusan di desa Cisarua yang masih dilakukan secara manual dimana tidak ada metode yang digunakan dalam prosesnya menyebabkan pihak pembuat keputusan dihadapkan dengan masalah pertimbangan penerima bantuan dengan jumlah masyarakat dan kriteria yang tidak sedikit. Hal tersebut menyebabkan perlunya waktu yang lama dalam proses penentuan pemberian bantuan, menimbulkan penilaian yang bersifat subjektif dan pemberian bantuan yang tidak tepat sasaran. Simple Additive Weighting (SAW) dan Weighted Product (WP) merupakan metode pengambilan keputusan multikriteria yang dapat diterapkan dalam proses penentuan pemberian bantuan, keduanya dibandingkan untuk mendapatkan hasil perangkingan dan metode terbaik dalam menentukan penerimaan bantuan yang sesuai dan tepat sasaran. Penelitian dimulai dari tahap identifikasi masalah mencakup pengumpulan data, analisis, penerapan metode multikriteria hingga interpretasi hasil perbandingan metode multikriteria tersebut pada keputusan pemberian bantuan. Metode SAW lebih sesuai dan tepat diterapkan pada proses penentuan pemberian bantuan di desa Cisarua dengan menghasilkan jumlah peringkat yang lebih banyak dan nilai persentase tingkat kesesuaian yang lebih tinggi dari metode WP.
\end{abstract}

Kata kunci-Bantuan Sosial, Multi-criteria Decision Making, Simple Additive Weighting (SAW), Weighted Product (WP)

Abstract

Providing assistance is one of the programs carried out by the government through representatives of each region to help community's economy, especially those affected by Covid-19 pandemic. Ideally, the determination of the provision of assistance can be done quickly, objectively and on target. However, the decision-making process that is still done manually where there is no method used in its process, leads decision makers to face problems in determining assistance recipients with the large number of people and multicriteria. Thus requiring a long time in the decision-making process, leading to subjective judgments and providing assistance that is not on target. Simple Additive Weighting (SAW) and Weighted Product (WP) are decision-making multicriteria methods that can be applied in this research, both methods will be compared to obtain the ranking results and the best method in determining the appropriate and targeted assistance recipients. The research starts from the problem 
identification which includes data collection, analysis and application of the multicriteria method to the interpretation of method comparison results. The SAW method is more appropriate to be applied in determining the provision of assistance in Cisarua village by producing a higher number of rankings and value of suitability level than the WP method.

Keywords-Multi-criteria Decision Making, Simple Additive Weighting (SAW), Social Asisstance, Weighted Product (WP)

\section{PENDAHULUAN}

$\mathrm{P}_{\mathrm{s}}^{\mathrm{c}}$ mberian bantuan merupakan salah satu program yang dilakukan pemerintah untuk membantu masyarakat berkaitan dengan masalah yang disebabkan oleh pandemic Virus Corona. Program ini diadakan untuk meringankan beban masyarakat kelas menengah ke bawah dalam menghidupi kehidupan sehari-hari. Daerah desa Cisarua Kabupaten Sukabumi telah mengupayakan memberikan pelayanan berupa bantuan untuk membantu masyarakat melalui perwakilan setiap Rukun Tetangga (RT) di RW 11. Prioritas utama pemberian bantuan ini adalah masyarakat yang memang benar-benar perlu dan layak mendapatkan bantuan.

Proses penentuan keputusan penerimaan bantuan di RT 1, 2, 3 dan 4 RW 11 Desa Cisarua masih dilakukan secara manual. Idealnya penentuan keputusan pemberian bantuan dapat dilakukan dengan cepat, bersifat objektif dan tepat sasaran. Tepat sasaran yang dimaksud artinya pihak yang menerima bantuan benar-benar sesuai dan layak dengan kriteria yang telah ditentukan. Namun dengan proses yang masih dilakukan secara manual dimana belum ada metode yang digunakan dalam pengambilan keputusan, pihak pembuat keputusan dihadapkan dengan masalah pertimbangan penentuan keputusan dengan kriteria dan jumlah masyarakat yang tidak sedikit. Hal tersebut menyebabkan terjadinya keterlambatan, penilaian yang bersifat subjektif dan ketidak tepatan dalam menentukan pihak mana saja yang berhak dan layak menerima bantuan tersebut. Direktur Jenderal Anggaran Kementrian Keuangan mengatakan bahwa target penerima bantuan sosial masih kurang tepat sasaran dan duplikasi [1].

Proses untuk menentukan kelayakan pemberian bantuan merupakan permasalahan yang memerlukan beberapa kriteria yang dinilai, sehingga memerlukan metode yang dapat menyelesaikan masalah pengambilan keputusan multikriteria. Multi-citeria Decision Making (MCDM) adalah salah satu teknik yang digunakan untuk memilih altrenatif yang paling optimal dengan mempertimbangkan banyak kriteria untuk tujuan tertentu. Metode MCDM bersifat objektif dan membandingkan alternatif secara relative untuk memperkirakan nilai prioritas dari alternatif. Terdapat banyak jenis teknik MCDM yang digunakan belakangan ini, diantaranya adalah Simple Additive Weighting dan Weighted Product [2]. Metode SAW dikenal secara luas dan digunakan untuk menyelesaikan permasalahan multi-criteria decision making (MCDM) [3]. Konsep dasar metode SAW adalah mencari penjumlahan terbobot dari rating kinerja setiap alternatif pada semua atribut. Metode SAW membutuhkan proses normalisasi matriks keputusan (X) ke suatu skala yang dapat dibandingkan dengan semua rating alternatif yang ada[4]. Sedangkan metode WP memerlukan proses normalisasi karena metode ini mengalikan hasil penilaian setiap atribut [5]. Pada penelitian untuk menentukan kelayakan penerima bantuan siswa miskin (BSM), metode Simple Additive Weighting (SAW) menghasilkan daftar peringkat calon penerima beasiswa secara efektif dan tepat sasaran sesuai dengan persyaratan yang ditentukan[6]. Penelitian lain dilakukan untuk menentukan penerima bantuan social yang tepat sasaran dan layak dengan menggunakan metode WP. Penelitian ini menghasilkan daftar alternatif penerima bantuan dari nilai tertinggi sampai terendah yang membantu pengambil keputusan dalam menentukan keputusan yang bersifat objektif dan dilakukan dengan cepat [7].

Rizka, (Perbandingan Simple Additive Weighting Dan Weighted Product Pada Keputusan Pemberian Bantuan (Desa Cisarua) 
Penelitian lain dalam menentukan keputusan kelayakan pemberian bantuan dilakukan untuk menentukan bisnis kecil yang layak menerima bantuan keuangan atau kredit dari Bank Negara Indonesia. Penelitian ini menghasilkan daftar peringkat rekomendasi pihak yang pantas menerima bantuan kredit tunai sesuai dengan kriteria yang diutamakan dengan menggunakan metode SAW [8]. Penelitian lain dilakukan untuk menentukan penerima beasiswa yang masih dilakukan secara manual sehingga menyebabkan distribusi beasiswa yang tidak tepat sasaran dan memerlukan waktu yang lama dalam menentukan keputusannya. Penelitian menggunakan metode SAW ini menghasilkan daftar calon penerima beasiswa yang tepat sasaran dan proses pengambilan keputusan dapat dilakukan dengan cepat [9]. Penelitian menggunakan metode WP lainnya dilakukan dalam menentukan pihak yang layak menerima Bidik Misi di SMIK Pringsewu. Penelitian ini menghasilkan daftar siswa yang layak dan pantas menerima Bidik Misi sesuai dengan kriteria dan persyaratan yang telah ditentukan [10]. Penelitian terakhir yang digunakan sebagai referensi pada penelitian ini adalah penelitian yang dilakukan untuk menentukan penerimaan karyawan baru dengan mengimplementasikan metode SAW dan WP. Kedua metode tersebut berhasil menghasilkan hasil peringkat untuk nilai akhir karyawan yang diterima. Metode SAW menghasilkan hasil peringkat yang lebih jelas daripada metode WP dan metode WP menunjukan waktu eksekusi yang lebih baik daripada metode SAW [11].

Penelitian-penelitian yang pernah dilakukan sebelumnya menunjukkan penggunaan metode yang berbeda dalam menyelesaikan masalah pengambilan keputusan multikriteria. Maka dari itu berdasarkan permasalahan dan penjelasan yang telah dipaparkan, penulis membandingkan metode multikriteria Simple Additive Weighting (SAW) dan Weighted Product (WP) untuk melihat hasil perhitungan dan perangkingan serta mendapatkan metode yang lebih sesuai dan tepat untuk digunakan dalam penyelesaian masalah pengambilan keputusan pemberian bantuan di RT 1, 2, 3 dan 4 RW 11 Desa Cisarua.

\section{METODE PENELITIAN}

Penelitian yang dilakukan merupakan penelitian dengan metode studi kasus dimana objek pada penelitian ini adalah pemberian bantuan pada warga RT 1, 2, 3 dan 4 RW 11 Desa Cisarua Kabupaten Sukabumi. Tahap penelitian pada penelitian ini dilakukan melalui tahap seperti pada gambar 1.

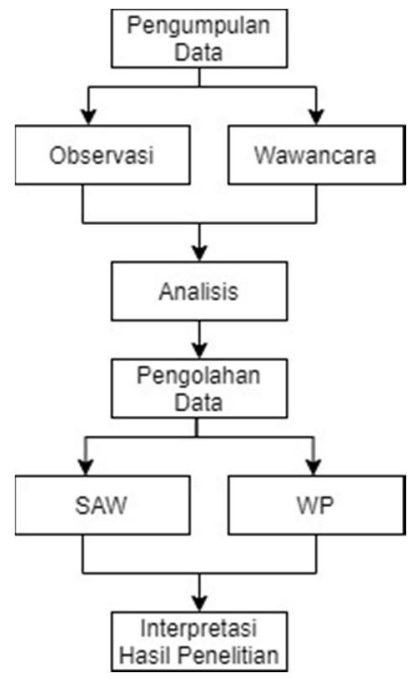

Gambar 1. Tahap Penelitian

Rizka, (Perbandingan Simple Additive Weighting Dan Weighted Product Pada Keputusan Pemberian Bantuan (Desa Cisarua) 
1. Pengumpulan Data. Data yang diperlukan pada penelitian ini diperoleh melalui wawancara dan observasi. Observasi dilakukan dengan mengidentifikasi proses pengambilan keputusan pemberian bantuan oleh ketua RT sebagai pihak pengambil keputusan. Wawancara dilakukan untuk mengumpulkan informasi data warga calon penerima bantuan, kriteria dan syarat yang diperlukan sebagai bahan pertimbangan pemberian keputusan. Data yang diperoleh yaitu data warga RT 1, 2, 3 dan 4 RW 11 desa Cisarua yang terdiri dari nama warga, status pekerjaan, jumlah penghasilan, status kepemilikan rumah serta jumlah tanggungan keluarga.

2. Analisis. Tahap ini mencakup proses analisis mengenai data calon penerima bantuan, kriteria dan syarat yang diperlukan, metode multikriteria Simple Additive Weighting dan Weighted Product serta bagaimana penerapan metode multikriteria tersebut dalam penentuan keputusan pemberian bantuan di desa Cisarua.

3. Pengolahan Data. Data yang sudah didapatkan dan dianalisis kemudian diolah dengan metode pengambilan keputusan multikriteria Simple Additive Weighting dan Weighted Product secara manual untuk mendapatkan hasil perankingan penerima bantuan di RT 1, 2, 3 dan 4 RW 11 desa Cisarua.

4. Interpretasi Hasil Penelitian. Pada tahap ini dilakukan interpretasi hasil penelitian yang sudah dilakukan dengan membandingkan hasil daftar ranking alternatif penerima bantuan dan persentase nilai tingkat kesesuaian yang diperoleh dari penerapan metode Simple Additive Weighting dan Weighted Product yang diujikan pada studi kasus pemberian bantuan di desa Cisarua.

\section{HASIL DAN PEMBAHASAN}

Model matematika yang digunakan untuk menentukan keputusan pemberian bantuan pada penelitian ini adalah SAW dan WP. Keduanya dibandingan untuk memperoleh metode yang lebih tapat dalam keputusan pemberian bantuan yang sesuai dengan kriteria yang telah ditentukan. Tabel 1 menunjukkan kriteria yang telah ditentukan oleh pihak pengambil keputusan (RT) sebagai pertimbangkan pemberian bantuan di RT 1, 2, 3 dan 4 RW 11 desa Cisarua.

Tabel 1. Kriteria

\begin{tabular}{|c|l|l|c|}
\hline Kriteria & \multicolumn{1}{|c|}{ Keterangan } & \multicolumn{1}{c|}{ Kategori } & Bobot \\
\hline C1 & Status Pekerjaan & Cost (Biaya) & 25 \\
\hline C2 & Jumlah Penghasilan & Cost (Biaya) & 45 \\
\hline C3 & Status Kepemilikan Rumah & Cost (Biaya) & 15 \\
\hline C4 & Jumlah Tanggungan & Benefit (Keuntungan) & 15 \\
\hline
\end{tabular}

Rating kecocokan untuk setiap alternatif dengan setiap kriteria adalah sebagai berikut:

Sangat Rendah $=1$

Rendah $\quad=2$

Cukup $\quad=3$

Tinggi $\quad=4$

Sangat Tinggi $=5$

Nilai atau bobot pada setiap alternatif yang telah ditentukan adalah sebagai berikut:

1. Kriteria Status Pekerjaan

Status pekerjaan dapat dilihat dari pekerjaan yang dimiliki oleh setiap alternatif yang dibagi ke dalam 5 kategori oleh pihak pengambil keputusan seperti yang ditunjukkan pada tabel 2 .

Rizka, (Perbandingan Simple Additive Weighting Dan Weighted Product Pada Keputusan Pemberian Bantuan (Desa Cisarua) 
Tabel 2. Nilai/Bobot Kriteria Status Pekerjaan

\begin{tabular}{|l|c|}
\hline Status Pekerjaan & Nilai/Bobot \\
\hline Tidak Bekerja & 1 \\
\hline Tidak Tetap & 2 \\
\hline Pedagang Kecil & 3 \\
\hline Pensiunan & 4 \\
\hline Lain-lain & 5 \\
\hline
\end{tabular}

2. Kriteria Jumlah Penghasilan

Kriteria jumlah penghasilan dilihat dari rata-rata jumlah penghasilan perbulan setiap warga di RT 1, 2, 3 dan 4 yang dibagi ke dalam 5 kategori yang ditunjukkan pada tabel 3.

Tabel 3. Nilai/Bobot Kriteria Jumlah Penghasilan

\begin{tabular}{|c|c|}
\hline $\begin{array}{c}\text { Jumlah Penghasilan } \\
\text { (Rupiah) }\end{array}$ & Nilai/Bobot \\
\hline$<=500.000$ & 1 \\
\hline$>500.000-2.000 .000$ & 2 \\
\hline$>2.000 .000-3.500 .000$ & 3 \\
\hline$>3.500 .000-5.000 .000$ & 4 \\
\hline$>5.000 .000$ & 5 \\
\hline
\end{tabular}

3. Kriteria Status Kepemilikan Rumah

Kriteria status kepemilikan rumah dilihat dari status kepemilikan rumah tempat setiap warga tinggal yang dibagi ke dalam 3 kategori seperti pada tabel 4 .

Tabel 4. Nilai/Bobot Kriteria Status Kepemilikan Rumah

\begin{tabular}{|l|c|}
\hline \multicolumn{1}{|c|}{ Status Kepemilikan Rumah } & Nilai/Bobot \\
\hline Rumah Kontrak/Sewa & 1 \\
\hline Rumah Saudara/Anak & 2 \\
\hline Rumah Sendiri & 3 \\
\hline
\end{tabular}

4. Kriteria Jumlah Tanggungan Keluarga

Kriteria jumlah tanggungan keluarga dilihat dari jumlah anggota keluarga yang masih perlu dibiayai yang ditanggung oleh kepala keluarga seperti yang ditunjukkan pada tabel 5.

Tabel 5. Nilai/Bobot Kriteria Jumlah Tanggungan Keluarga

\begin{tabular}{|c|c|}
\hline Jumlah Tanggungan Keluarga & Nilai/Bobot \\
\hline 1 & 1 \\
\hline 2 & 2 \\
\hline 3 & 3 \\
\hline 4 & 4 \\
\hline$>=5$ & 5 \\
\hline
\end{tabular}

\subsection{Penerapan Metode Simple Additive Weighting (SAW)}

Proses perangkingan untuk mendapatkan penerima bantuan dilakukan berdasarkan data warga pada setiap RT di RW 11. Terdapat 4 hasil perangkingan pada penelitian ini yaitu perangkingan penerima bantuan warga RT 1,2, 3 dan 4 . 
Pengolahan Data Warga RT 1

Tabel 6 merupakan data 44 warga RT 1 sebagai calon penerima bantuan yang memuat status pekerjaan, total penghasilan, kepemilikan rumah dan jumlah tanggungan keluarga.

Tabel 6. Data Warga RT 1

\begin{tabular}{|c|c|l|c|c|c|}
\hline \multirow{2}{*}{ No. } & \multirow{2}{*}{ Alternatif } & \multicolumn{4}{|c|}{ Kriteria } \\
\cline { 3 - 6 } & Status Pekerjaan & $\begin{array}{c}\text { Total Penghasilan } \\
\text { (Rupiah) }\end{array}$ & $\begin{array}{c}\text { Kepemilikan } \\
\text { Rumah }\end{array}$ & $\begin{array}{c}\text { Jumlah } \\
\text { Tanggungan }\end{array}$ \\
\hline 1 & Warga 1 & Buruh Bangunan & 1.000 .000 & Rumah Kontrak & 2 \\
\hline 2 & Warga 2 & Tidak Bekerja & 800.000 & Rumah Anak & 2 \\
\hline 3 & Warga 3 & Pedagang & 1.800 .000 & Rumah Kontrak & 3 \\
\hline 4 & Warga 4 & Tidak Bekerja & 400.000 & Rumah Kontrak & 2 \\
\hline 5 & Warga 5 & Buruh Bangunan & 1.200 .000 & Rumah Pribadi & 4 \\
\hline & $\vdots$ & $\vdots$ & $\vdots$ & $\vdots$ & $\vdots$ \\
\hline 44 & Warga 44 & Pensiunan & 7.000 .000 & Rumah Pribadi & 1 \\
\hline
\end{tabular}

Data warga yang diperoleh selanjutnya dikonversi sesuai dengan rating kecocokan. Data warga RT 1 calon penerima bantuan yang sudah dikonversi ditunjukan pada tabel 7.

Tabel 7. Data Warga RT 1 (Dikonversi)

\begin{tabular}{|c|l|c|c|c|c|}
\hline \multirow{2}{*}{ No. } & \multirow{2}{*}{ Alternatif } & \multicolumn{4}{|c|}{ Kriteria } \\
\cline { 3 - 6 } & & C1 & C2 & C3 & C4 \\
\hline 1 & Warga 1 & 2 & 2 & 1 & 2 \\
\hline 2 & Warga 2 & 1 & 2 & 2 & 2 \\
\hline 3 & Warga 3 & 3 & 2 & 1 & 3 \\
\hline 4 & Warga 4 & 1 & 1 & 1 & 2 \\
\hline 5 & Warga 5 & 2 & 2 & 3 & 4 \\
\hline & $\vdots$ & $\vdots$ & $\vdots$ & $\vdots$ & $\vdots$ \\
\hline 44 & Warga 44 & 4 & 5 & 3 & 1 \\
\hline
\end{tabular}

Langkah selanjutnya yang dilakukan setelah menentukan kriteria, bobot, serta tabel rating kecocokan antara data setiap alternatif dengan kriteria adalah membentuk matriks $\mathrm{X}$ dari tabel data warga yang telah dikonversi. Matriks keputusan X yang terbentuk berdasarkan tabel 7 adalah sebagai berikut:

$$
\mathbf{X}=\left|\begin{array}{cccc}
2 & 2 & 1 & 2 \\
1 & 2 & 2 & 2 \\
3 & 2 & 1 & 3 \\
1 & 1 & 1 & 2 \\
2 & 2 & 3 & 4 \\
\vdots & \vdots & \vdots & \vdots \\
4 & 5 & 3 & 1
\end{array}\right|
$$

Normalisasi matrix $\mathrm{X}$ dilakukan setelah matrix keputusan $\mathrm{X}$ dibentuk untuk menghitung nilai dari setiap kriteria dengan persamaan sebagai berikut:

$$
r i j=\left\{\begin{array}{l}
\frac{x_{i j}}{\max _{i} x_{i j}}, j i k a j \text { adalah atribut benefit } \\
\frac{\min _{i} x_{i j}}{x_{i j}}, \text { jika } j \text { adalah atribut cost }
\end{array}\right.
$$

Rizka, (Perbandingan Simple Additive Weighting Dan Weighted Product Pada Keputusan Pemberian Bantuan (Desa Cisarua) 
Keterangan:

$\mathrm{Rij} \quad=$ rating kinerja ternormalisasi

$\mathrm{Xij} \quad=$ nilai atribut yang dimiliki setiap kriteria

Max xij = nilai terbesar dari setiap kriteria

Min $x i j=$ nilai terkecil dari setiap kriteria

Max $\mathrm{x}_{\mathrm{ij}}$ digunakan untuk kriteria benefit (keuntungan) dan Min $\mathrm{x}_{\mathrm{ij}}$ digunakan untuk kriteria cost (biaya). Di bawah ini adalah hasil perhitungan dari setiap masing-masing kriteria (C) pada 44 data warga RT 1 RW 11 desa Cisarua.

C1 (Kriteria Status Pekerjaan)

$r_{1,1}=\frac{\operatorname{Min}(2,1,3,1,2, \ldots, 4)}{2}=\frac{1}{2}=0.500$

$r_{2,1}=\frac{\operatorname{Min}(2,1,3,1,2, \ldots, 4)}{1}=\frac{1}{1}=1.000$

$r_{3,1}=\frac{\operatorname{Min}(2,1,3,1,2, \ldots, 4)}{3}=\frac{1}{3}=0.333$

$r_{4,1}=\frac{\operatorname{Min}(2,1,3,1,2, \ldots, 4)}{1}=\frac{1}{1}=1.000$

$r_{5,1}=\frac{\operatorname{Min}(2,1,3,1,2, \ldots, 4)}{2}=\frac{1}{2}=0.500$

$r_{44,1}=\frac{\operatorname{Min}(2,1,3,1,2, \ldots, 4)}{4}=\frac{1}{4}=0.250$

C2 (Kriteria Jumlah Penghasilan)

$r_{1,2}=\frac{\operatorname{Min}(2,2,2,1,2, \ldots, 5)}{2}=\frac{1}{2}=0.500$

$r_{2,2}=\frac{\operatorname{Min}(2,2,2,1,2, \ldots, 5)}{2}=\frac{1}{2}=0.500$

$r_{3,2}=\frac{\operatorname{Min}(2,2,2,1,2, \ldots, 5)}{2}=\frac{1}{2}=0.500$

$r_{4,2}=\frac{\operatorname{Min}(2,2,2,1,2, \ldots, 5)}{1}=\frac{1}{1}=1.000$

$r_{5,2}=\frac{\operatorname{Min}(2,2,2,1,2, \ldots, 5)}{2}=\frac{1}{2}=0.500$

$r_{44,2}=\frac{\operatorname{Min}(2,2,2,1,2, \ldots, 5)}{5}=\frac{1}{5}=0.200$

C3 (Kriteria Status Kepemilikan Rumah)

$r_{1,3}=\frac{\operatorname{Min}(1,2,1,1,3, \ldots, 3)}{1}=\frac{1}{1}=1.000$

$r_{2,3}=\frac{\operatorname{Min}(1,2,1,1,3, \ldots, 3)}{2}=\frac{1}{2}=0.500$

$r_{3,3}=\frac{\operatorname{Min}(1,2,1,1,3, \ldots, 3)}{1}=\frac{1}{1}=1.000$

$r_{4,3}=\frac{\operatorname{Min}(1,2,1,1,3, \ldots, 3)}{1}=\frac{1}{1}=1.000$

$r_{5,3}=\frac{\operatorname{Min}(1,2,1,1,3, \ldots, 3)}{3}=\frac{1}{3}=0.333$

Rizka, (Perbandingan Simple Additive Weighting Dan Weighted Product Pada Keputusan Pemberian Bantuan (Desa Cisarua) 
$r_{44,3}=\frac{\operatorname{Min}(1,2,1,1,3, \ldots, 3)}{3}=\frac{1}{3}=0.333$

C4 (Kriteria Jumlah Tanggungan Keluarga)

$r_{1,4}=\frac{2}{\operatorname{Max}(2,2,3,2,4, \ldots, 1)}=\frac{2}{5}=0.400$

$r_{2,4}=\frac{2}{\operatorname{Max}(2,2,3,2,4, \ldots, 1)}=\frac{2}{5}=0.400$

$r_{3,4}=\frac{3}{\operatorname{Max}(2,2,3,2,4, \ldots, 1)}=\frac{3}{5}=0.600$

$r_{4,4}=\frac{2}{\operatorname{Max}(2,2,3,2,4, \ldots, 1)}=\frac{2}{5}=0.400$

$r_{5,4}=\frac{4}{\operatorname{Max}(2,2,3,2,4, \ldots, 1)}=\frac{4}{5}=0.800$

$r_{44,4}=\frac{1}{\operatorname{Max}(2,2,3,2,4, \ldots, 1)}=\frac{1}{5}=0.200$

Hasil normalisasi matriks $\mathrm{X}$ dengan persamaan (1) dapat dilihat pada tabel 8 sebagai berikut:

Tabel 8. Hasil Normalisasi Matriks X RT 1

\begin{tabular}{|c|c|c|c|c|c|}
\hline \multirow{2}{*}{ No. } & \multirow{2}{*}{ Alternatif } & \multicolumn{4}{|c|}{ Kriteria } \\
\cline { 3 - 6 } & & $\mathbf{C 1}$ & $\mathbf{C 2}$ & $\mathbf{C 3}$ & $\mathbf{C 4}$ \\
\hline 1 & Warga 1 & 0.500 & 0.500 & 1.000 & 0.400 \\
\hline 2 & Warga 2 & 1.000 & 0.500 & 0.500 & 0.400 \\
\hline 3 & Warga 3 & 0.333 & 0.500 & 1.000 & 0.600 \\
\hline 4 & Warga 4 & 1.000 & 1.000 & 1.000 & 0.400 \\
\hline 5 & Warga 5 & 0.500 & 0.500 & 0.333 & 0.800 \\
\hline & $\vdots$ & $\vdots$ & $\vdots$ & $\vdots$ & $\vdots$ \\
\hline 44 & Warga 44 & 0.250 & 0.200 & 0.333 & 0.200 \\
\hline
\end{tabular}

Matriks ternormalisasi R dibentuk dari tabel 8 dengan hasil sebagai berikut:

$$
\mathbf{R}=\left|\begin{array}{cccc}
0.500 & 0.500 & 1.000 & 0.400 \\
1.000 & 0.500 & 0.500 & 0.400 \\
0.333 & 0.500 & 1.000 & 0.600 \\
1.000 & 1.000 & 1.000 & 0.400 \\
0.500 & 0.500 & 0.333 & 0.800 \\
\vdots & \vdots & \vdots & \vdots \\
0.250 & 0.200 & 0.333 & 0.200
\end{array}\right|
$$

Matriks ternormalisasi $\mathrm{R}$ kemudian dikalikan dengan vektor bobot kriteria dengan persamaan:

Keterangan:

$$
V_{i}=\sum_{j=1}^{n} W_{j} r_{i j}
$$

$\mathrm{Vi} \quad=$ rangking untuk setiap alternatif (A)

Rizka, (Perbandingan Simple Additive Weighting Dan Weighted Product Pada Keputusan Pemberian Bantuan (Desa Cisarua) 
$\mathrm{Wj} \quad=$ nilai bobot dari setiap kriteria $(\mathrm{C})$

$\mathrm{Rij} \quad=$ nilai rating kinerja ternormalisasi

Perkalian matriks dan bobot ini akan menghasilkan perangkingan calon penerima bantuan dari nilai preferensi terbesar sampai terkecil yang akan dijadikan keputusan pemberian bantuan di RT 1 RW 11 desa Cisarua. Nilai akhir yang diperoleh oleh masing-masing alternatif (A) penerima bantuan adalah sebagai berikut:

$$
\begin{aligned}
& \text { V1 }=(0.500 \times 0.25)+(0.500 \times 0.45)+(1.000 \times 0.15)+(0.400 \times 0.15)=0.560 \\
& \text { V2 }=(1.000 \times 0.25)+(0.500 \times 0.45)+(0.500 \times 0.15)+(0.400 \times 0.15)=0.610 \\
& \text { V3 }=(0.333 \times 0.25)+(0.500 \times 0.45)+(1.000 \times 0.15)+(0.600 \times 0.15)=0.548 \\
& \text { V4 }=(1.000 \times 0.25)+(1.000 \times 0.45)+(1.000 \times 0.15)+(0.400 \times 0.15)=0.910 \\
& \text { V5 }=(0.500 \times 0.25)+(0.500 \times 0.45)+(0.333 \times 0.15)+(0.800 \times 0.15)=0.520 \\
& \vdots \\
& \text { V44 }=(0.250 \times 0.25)+(0.200 \times 0.45)+(0.333 \times 0.15)+(0.200 \times 0.15)=0.233
\end{aligned}
$$

Hasil nilai preferensi menunjukkan ranking tertinggi sampai terendah pada penerima bantuan di RT 1. V4 alternatif A4 (Warga 4) adalah peringkat dengan nilai preferensi tertinggi, diikuti oleh V2 yaitu alternatif A2 (Warga 2), V1 alternatif A1 (Warga 1), V3 alternatif A3 (Warga 3), V5 alternatif A5 (Warga 5) dan V44 alternatif A44 (Warga 44) dengan nilai preferensi terendah.

Penerapan metode SAW pada RT 2, 3, dan 4 dilakukan seperti pada RT 1.

\section{2. $\quad$ Penerapan Metode Weighted Product (WP)}

Terdapat 4 hasil perangkingan pada penelitian ini yaitu perangkingan penerima bantuan warga RT 1, 2, 3 dan 4. Perbaikan bobot selanjutnya dilakukan setelah kriteria dan syarat telah ditentukan. Bobot awal pada tabel 1 dimana $\mathrm{W}=(25,45,15,15)$ diperbaiki sehingga total bobot $\sum W j=1$ dengan persamaan sebagai berikut:

$$
W j=\frac{W j}{\sum \mathrm{Wj}_{\mathrm{j}}}
$$

Perbaikan bobot dengan persamaan 3 adalah sebagai berikut:

$\mathrm{W}_{1}=\frac{25}{25+45+15+15}=\frac{25}{100}=0.25$

$\mathrm{W}_{2}=\frac{45}{25+45+15+15}=\frac{45}{100}=0.45$

$\mathrm{W}_{3}=\frac{15}{25+45+15+15}=\frac{15}{100}=0.15$

$\mathrm{W}_{4}=\frac{15}{25+45+15+15}=\frac{15}{100}=0.15$

\section{Pengolahan Data Warga RT 1}

Proses yang dilakukan setelah melakukan perbaikan (normalisasi) bobot adalah menghitung vektor S pada setiap alternatif (Ai). Nilai preferensi 44 alternatif (Data warga) RT 1 yang terkonversi dengan rating kecocokan pada tabel 7 dihitung menggunakan persamaan sebagai berikut:

$$
S i=\prod_{j=1}^{n} X i j^{w j}
$$

Wj bernilai positif digunakan untuk kriteria benefit (keuntungan) dan $\mathrm{Wj}$ bernilai negatif digunakan untuk kriteria cost (biaya).

S1 $=\left(2^{-0.25}\right) \times\left(2^{-0.45}\right) \times\left(1^{-0.15}\right) \times\left(2^{0.15}\right)=0.683$
S2 $=\left(1^{-0.25}\right) \times\left(2^{-0.45}\right) \times\left(2^{-0.15}\right) \times\left(2^{0.15}\right)=0.732$
S3 $=\left(3^{-0.25}\right) \times\left(2^{-0.45}\right) \times\left(1^{-0.15}\right) \times\left(3^{0.15}\right)=0.656$




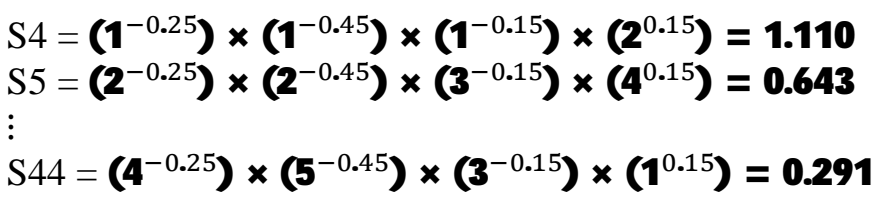

Perangkingan penerima bantuan dilakukan setelah mendapatkan nilai vektor $\mathrm{S}$ dengan melakukan perhitungan vektor $\mathrm{V}$ menggunakan persamaan sebagai berikut:

$$
V i=\frac{\prod_{j=1}^{n} X i j^{w j}}{\prod_{j=1}^{n}(X j) w j}
$$

Perhitungan nilai preferensi relatif setiap atribut dilakukan dengan membagi nilai $\mathrm{Si}$ dengan $\Sigma S i$ menggunakan persamaan 5 adalah sebagai berikut:

$$
\begin{aligned}
& \mathrm{V}_{1}=\frac{0.683}{0.638+0.732+0.656+1.110+0.643+\cdots+0.291}=\frac{0.683}{18.533}=0.0369 \\
& \mathrm{~V}_{2}=\frac{0.732}{0.638+0.732+0.656+1.110+0.643+\cdots+0.291}=\frac{0.732}{18.533}=0.0395 \\
& \mathrm{~V}_{3}=\frac{0.656}{0.638+0.732+0.656+1.110+0.643+\cdots+0.291}=\frac{0.656}{18.533}=0.0354 \\
& \mathrm{~V}_{4}=\frac{1.110}{0.638+0.732+0.656+1.110+0.643+\cdots+0.291}=\frac{1.110}{18.533}=0.0599 \\
& \mathrm{~V}_{5}=\frac{0.643}{0.638+0.732+0.656+1.110+0.643+\cdots+0.291}=\frac{0.643}{18.533}=0.0347 \\
& \vdots \\
& V_{44}=\frac{0.291}{0.683+0.732+0.656+1.110+0.643+\cdots+0.291}=\frac{0.291}{18.533}=0.0157
\end{aligned}
$$

Hasil nilai preferensi menunjukkan ranking tertinggi sampai terendah pada penerima bantuan di RT 1 menggunakan metode WP. V4 alternatif A4 (Warga 4) adalah peringkat dengan nilai preferensi tertinggi, diikuti oleh V2 yaitu alternatif A2 (Warga 2), V1 alternatif A1 (Warga 1), V3 alternatif A3 (Warga 3), dan V5 alternatif A5 (Warga 5).

Penerapan metode WP pada RT 2, 3 dan 4 dilakukan seperti pada RT 1.

\subsection{Perbandingan Metode SAW dan WP}

\subsubsection{Perbandingan Metode SAW dan WP pada Data RT 1}

Perbandingan hasil perangkingan pemberian bantuan di RT 1 RW 11 desa Cisarua menggunakan metode Simple Additive Weighting dan Weighted Product ditunjukan pada tabel 9.

Tabel 9. Perbandingan Hasil Perangkingan SAW dan WP pada RT 1

\begin{tabular}{|c|c|c|l|c|c|}
\hline Alternatif & SAW & Ranking & Alternatif & WP & Ranking \\
\hline Warga 4 & 0.0910 & 1 & Warga 4 & 0.0599 & 1 \\
\hline Warga 2 & 0.0610 & 2 & Warga 2 & 0.0395 & 2 \\
\hline Warga 1 & 0.0560 & 3 & Warga 1 & 0.0369 & 3 \\
\hline Warga 3 & 0.0548 & 4 & Warga 3 & 0.0354 & 4 \\
\hline Warga 5 & 0.0520 & 5 & Warga 5 & 0.0347 & 5 \\
\hline$\vdots$ & $\vdots$ & $\vdots$ & $\vdots$ & $\vdots$ & $\vdots$ \\
\hline Warga 44 & 0.233 & 28 & Warga 44 & 0.0157 & 26 \\
\hline
\end{tabular}

Perbandingan metode SAW dan WP menunjukkan 5 alternatif tertinggi yaitu Warga 4, Warga 2, Warga 1, Warga 3 dan Warga 5 terpilih sebagai penerima bantuan yang sesuai dengan kriteria dan persyaratan yang sudah ditentukkan oleh pihak pengambil keputusan (pihak ketua $\mathrm{RT})$.

Rizka, (Perbandingan Simple Additive Weighting Dan Weighted Product Pada Keputusan Pemberian Bantuan (Desa Cisarua) 
Tingkat kesesuaian pada masing-masing metode dihitung menggunakan persamaan:

$$
\begin{gathered}
\text { Tki }=100-\frac{x i}{\operatorname{Data} M C D M(100 \%)} \\
\text { Tki SAW }=100-\frac{15.441}{44}=99.6491 \% \\
\text { Tki } W P=100-\frac{18.533}{44}=99.5788 \%
\end{gathered}
$$

Berdasarkan nilai tingkat kesesuaian, metode SAW menunjukkan hasil yang lebih tinggi yaitu $99.6491 \%$ dibandingkan dengan metode WP dengan tingkat kesesuaian 99.5788\%. Dari 44 data warga RT 1 yang diolah, metode SAW menghasilkan lebih banyak peringkat yaitu 28 peringkat, sementara metode WP menghasilkan 26 peringkat.

\subsubsection{Perbandingan Metode SAW dan WP pada Data RT 2}

Perbandingan hasil perangkingan pemberian bantuan di RT 2 RW 11 desa Cisarua menggunakan metode Simple Additive Weighting dan Weighted Product ditunjukan pada tabel 10.

Tabel 10. Perbandingan Hasil Perangkingan SAW dan WP pada RT 2

\begin{tabular}{|c|c|c|c|c|c|}
\hline Alternatif & SAW & Ranking & Alternatif & WP & Ranking \\
\hline Warga 47 & 0.825 & 1 & Warga 47 & 0.0629 & 1 \\
\hline Warga 46 & 0.600 & 2 & Warga 46 & 0.0460 & 2 \\
\hline Warga 45 & 0.513 & 3 & Warga 45 & 0.0411 & 3 \\
\hline Warga 49 & 0.508 & 4 & Warga 49 & 0.0388 & 4 \\
\hline Warga 48 & 0.475 & 5 & Warga 81 & 0.0350 & 5 \\
\hline$\vdots$ & $\vdots$ & $\vdots$ & $\vdots$ & $\vdots$ & $\vdots$ \\
\hline Warga 82 & 0.228 & 20 & Warga 82 & 0.0184 & 19 \\
\hline
\end{tabular}

Perbandingan metode SAW dan WP menunjukkan 5 alternatif tertinggi yaitu Warga 47, Warga 46, Warga 45, Warga 49 dan Warga 48 pada metode SAW serta Warga 49 pada metode WP terpilih sebagai penerima bantuan yang sesuai dengan kriteria dan persyaratan yang sudah ditentukkan oleh pihak pengambil keputusan (pihak ketua RT).

Tingkat kesesuaian pada masing-masing metode dihitung menggunakan rumus (6).

Tki SAW $=100-\frac{13.481}{38}=99.6452 \%$

Tki $W P=100-\frac{14.967}{38}=99.6061 \%$

Berdasarkan nilai tingkat kesesuaian, metode SAW menunjukkan hasil yang lebih tinggi yaitu 99.6543\% dibandingkan dengan metode WP dengan tingkat kesesuaian 99.6162\%. Dari 38 data warga RT 2 yang diolah, metode SAW menghasilkan lebih banyak peringkat yaitu 20 peringkat, sementara metode WP menghasilkan 19 peringkat.

\subsubsection{Perbandingan Metode SAW dan WP pada Data RT 3}

Perbandingan hasil perangkingan pemberian bantuan di RT 3 RW 11 desa Cisarua menggunakan metode Simple Additive Weighting dan Weighted Product ditunjukan pada tabel 11. 
Tabel 11. Perbandingan Hasil Perangkingan SAW dan WP pada RT 3

\begin{tabular}{|c|c|c|c|c|c|}
\hline Alternatif & SAW & Ranking & Alternatif & WP & Ranking \\
\hline Warga 87 & 0.810 & 1 & Warga 87 & 0.0499 & 1 \\
\hline Warga 85 & 0.590 & 2 & Warga 85 & 0.0385 & 2 \\
\hline Warga 84 & 0.578 & 3 & Warga 84 & 0.0363 & 3 \\
\hline Warga 86 & 0.533 & 4 & Warga 86 & 0.0313 & 4 \\
\hline Warga 83 & 0.478 & 5 & Warga 83 & 0.0308 & 5 \\
\hline$\vdots$ & $\vdots$ & $\vdots$ & $\vdots$ & $\vdots$ & $\vdots$ \\
\hline Warga 126 & 0.250 & 25 & Warga 126 & 0.0162 & 24 \\
\hline
\end{tabular}

Perbandingan metode SAW dan WP menunjukkan 5 alternatif tertinggi yaitu Warga 87, Warga 85 , Warga 84 , Warga 86 dan Warga 83 terpilih sebagai penerima bantuan yang sesuai dengan kriteria dan persyaratan yang sudah ditentukkan oleh pihak pengambil keputusan (pihak ketua RT).

Tingkat kesesuaian pada masing-masing metode dihitung menggunakan rumus (6).

Tki SAW $=100-\frac{15.907}{44}=99.638 \%$

Tki $W P=100-\frac{18.858}{44}=99.571 \%$

Berdasarkan perhitungan tingkat kesesuaian, metode SAW menunjukkan hasil yang lebih tinggi yaitu $99.638 \%$ dibandingkan dengan metode WP dengan tingkat kesesuaian $99.571 \%$. Dari 44 data warga RT 3 yang diolah, metode SAW menghasilkan lebih banyak peringkat yaitu 22 peringkat sementara metode WP menghasilkan 21 peringkat.

3.2.4. Perbandingan Metode SAW dan WP pada Data RT 4

Perbandingan hasil perangkingan pemberian bantuan di RT 4 RW 11 desa Cisarua menggunakan metode Simple Additive Weighting dan Weighted Product ditunjukan pada tabel 12.

Tabel 12. Perbandingan Hasil Perangkingan SAW dan WP pada RT 4

\begin{tabular}{|c|c|c|c|c|c|}
\hline Alternatif & SAW & Ranking & Alternatif & WP & Ranking \\
\hline Warga 130 & 0.870 & 1 & Warga 130 & 0.0728 & 1 \\
\hline Warga 129 & 0.650 & 2 & Warga 129 & 0.0547 & 2 \\
\hline Warga 131 & 0.645 & 3 & Warga 131 & 0.0533 & 3 \\
\hline Warga 128 & 0.518 & 4 & Warga 128 & 0.0430 & 4 \\
\hline Warga 127 & 0.460 & 5 & Warga 127 & 0.0404 & 5 \\
\hline$\vdots$ & $\vdots$ & $\vdots$ & $\vdots$ & $\vdots$ & $\vdots$ \\
\hline Warga 159 & 0.250 & 22 & Warga 159 & 0.0213 & 21 \\
\hline
\end{tabular}

Perbandingan metode SAW dan WP menunjukkan 5 alternatif tertinggi yaitu Warga 130, Warga 129, Warga 131, Warga 128 dan Warga 127 terpilih sebagai penerima bantuan yang sesuai dengan kriteria dan persyaratan yang sudah ditentukkan oleh pihak pengambil keputusan (pihak ketua RT).

Tingkat kesesuaian pada masing-masing metode dihitung menggunakan rumus (6).

Tki SAW $=100-\frac{12.366}{33}=99.62528 \%$

Tki $W P=100-\frac{14.339}{33}=99.56548 \%$

Berdasarkan perhitungan tingkat kesesuaian, metode SAW menunjukkan hasil yang lebih tinggi yaitu 99.62528\% dibandingkan dengan metode WP dengan tingkat kesesuaian 99.56548.

Rizka, (Perbandingan Simple Additive Weighting Dan Weighted Product Pada Keputusan Pemberian Bantuan (Desa Cisarua) 
Dari 33 data warga RT 4 yang diolah, metode SAW menghasilkan lebih banyak peringkat yaitu 22 peringkat, sementara metode WP menghasilkan 21 peringkat.

\section{KESIMPULAN}

Metode SAW dan WP menghasilkan 5 alternatif dengan nilai tertinggi yang sama sebagai pihak penerima bantuan di RT 1, 2, 3 dan 4 desa Cisarua. Terdapat beberapa perbedaan dalam hasil urutan perangkingan pada metode SAW dan WP yang dipengaruhi oleh beberapa faktor seperti nilai rating kinerja setiap alternatif, bobot kriteria dan perhitungan matematika pada setiap metode.

Penelitian ini menunjukan bahwa metode SAW lebih sesuai dan tepat untuk diterapkan pada proses penentuan keputusan pemberian bantuan di desa Cisarua dengan menghasilkan jumlah peringkat yang lebih banyak dan nilai persentase tingkat kesesuaian yang lebih tinggi dibandingkan dengan metode WP. Semakin banyak peringkat yang dihasilkan menunjukkan perhitungan dengan metode tersebut dapat meminimalisir nilai preferensi yang sama sehingga perangkingan alternatif penerima bantuan dapat dilakukan dengan baik dan memberikan hasil yang lebih jelas.

\section{SARAN}

Kriteria atau parameter lain yang berpotensi berpartisipasi sebagai bahan pertimbangan seperti status pendidikan dan status kepala keluarga, dapat diidentifikasi dalam proses perhitungan menggunakan metode yang ujikan untuk keputusan penerima bantuan pada penelitian selanjutnya. Identifikasi kriteria atau parameter lain digunakan untuk meminimalisir hasil perhitungan nilai preferensi yang sama sehingga dapat menghasilkan hasil perangkingan alternatif yang lebih jelas. Jenis metode multi-criteria decision making lain seperti Analytical Hierarchy Process (AHP), Electre, dan Fuzy Logic Decision Making (FLDM) juga dapat digunakan untuk penentuan keputusan pemberian bantuan sebagai pembanding dengan metode yang telah diuji pada penelitian ini.

\section{DAFTAR PUSTAKA}

[1] A. Indraini. 2020, Pemerintah Akui Penyaluran Bansos Kurang Tepat Sasaran, detikfinance, https://finance.detik.com/berita-ekonomi-bisnis/d-5016422/pemerintahakui-penyaluran-bansos-kurang-tepat-sasaran (accessed Sep. 24, 2020).

[2] M. Majumder and A. K. Saha. 2016, Feasibility Model of Solar Energy Plants by ANN and MCDM Techniques, no. April. Springer Briefs in Energy.

[3] G. H. Tzeng and J. J. Huang. 2011, Multiple Attribute Decision Making: Methods and Applications, CRC Press,.

[4] W. Setiyaningsih. 2015, Konsep Sistem Pendukung Keputusan, 1st ed. Malang: Yayasan Edelweis, 
[5] S. H. Kusumadewi, Fuzzy Multi-Attribute Decision Making (Fuzzy MADM), Graha Ilmu Yogyakarta, 2013.

[6] E. T. Cahyanul, S. D. Lestari, and H. Hermawan, Sistem Pendukung Keputusan Bagi Penerima Bantuan Siswa Miskin (BSM) Menggunakan Metode Simple Additive Weighting (SAW) di SMA Negeri 1 Raren Batuah Kabupaten Barito Timur, J. Appl. Informatics Comput., vol. 3, no. 2, pp. 114-118, 2019, doi: 10.30871/jaic.v3i2.1752.

[7] M. A. Saputera, A. Tejawati, and Masnawati, Sistem Pendukung Keputusan Penentuan Penerima Program Bantuan Daerah Menggunakan Weighted Product, Pros. SAKTI (Seminar Ilmu Komput. dan Teknol. Informasi), Vol. 2, No. 1, pp. 76-80, 2017, [Online]. Available: http://e-journals.unmul.ac.id/index.php/SAKTI/article/view/241.

[8] A. O. Riyandi, N. Dengen, and Islamiyah, Sistem Pendukung Keputusan Kelayakan Pemberian Bantuan Dana Atau Kredit Untuk Usaha Kecil Menengah (UKM) pada Bank Negara Indonesia (BNI), Pros. SAKTI (Seminar Ilmu Komput. dan Teknol. Informasi), Vol. 2, No. 1, pp. 8-13, 2017, [Online]. Available: http://ejournals.unmul.ac.id/index.php/SAKTI/article/view/230.

[9] M. Ibrohim, Decision Support System for Determining The Scholarship Recipients Using Simple Additive Weighting, Int. J. Comput. Appl., Vol. 151, No. 2, pp. 10-13, 2016, doi: 10.5120/ IJCA2016911679.

[10] M. Muslihudin and R. F. Andriyanti, Implementasi Metode Weighted Product Menentukan Beasiswa Bidik Misi Stmik Pringsewu, JATISI (Jurnal Tek. Inform. dan Sist. Informasi), Vol. 4, No. 2, pp. 156-163, 2018, doi: 10.35957/jatisi.v4i2.97.

[11] A. Setyawan, F. Y. Arini, and I. Akhlis, Comparative Analysis of Simple Additive Weighting Method and Weighted Product Method to New Employee Recruitment Decision Support System (DSS) at PT. Warta Media Nusantara, Sci. J. Informatics, Vol. 4, No. 1, pp. 34-42, 2017, doi: 10.15294/sji.v4i1.8458.

Rizka, (Perbandingan Simple Additive Weighting Dan Weighted Product Pada Keputusan Pemberian Bantuan (Desa Cisarua) 